Ірина Нестерова, аспірант відділу дидактики Інституту педагогіки НАПН Украӥни, м. Київ

\title{
РЕТРОСПЕКТИВНИЙ АНАЛІЗ СТАНОВЛЕННЯ ОНТОЛОГІЧНОГО СТАТУСУ СУБ'ЄКТНОСТІ У ПРОЦЕСІ САМОУСВІДОМЛЕННЯ ОСОБИСТОСТІ
}

У статті актуалізовано потребу втілення ідеї суб 'єктності особистості з педагогічної точки зору. 3 цією метою проаналізовано основні тенденції становлення уявлення про суб 'єктну сутність особистості у вітчизняній науковій традиції, розкривається специфіка людського способу існування як активно перетворююча, свідома, громадська діяльність; дано визначення суб 'єктності та суб'єкту, розглянуті основні атрибутивні характеристики цих особистісних властивостей. Розвиток поглядів на природу суб'єктності та ї̈ детермінацію розглянуто на основі існуючих періодизачій вивчення суб' єктної проблематики та які дозволили визначити генезис категорій “суб' єкт” “ “суб'єктність”. Виокремлено проблему узагальнення й інтерпретації різних варіантів розуміння науковиями суб'єктності з філософського, сочіального, психологічного й педагогічного поглядів.

Ключові слова: суб 'єкт; особистість; суб 'єктність; суб'єктні прояви; педагогічний процес.

Jim. 13.

Iryna Nesterova, Postgraduate Student of the Didactics Department, Institute of Pedagogics National Academy of Sciences of Ukraine, Kyiv

\section{RETROSPECTIVE ANALYSIS OF DEVELOPMENT OFTHE ONTOLOGICAL STATUS OF SUBJECTIVITY IN THE SELF-AWARENESS PROCESS}

The article actualized the idea of the implement of subjectivity of personality from a pedagogical point of view. For this purpose, the main tendencies of the formation of the notion of the subjectivity of the individual in the national scientific tradition are analyzed, the specificity of the human way of life as an actively transforming, conscious, social activity is revealed; the definition of subjectivity and subject, the main attributive characteristics of these personality properties are considered. The development of views on the essence of subjectivity and its determination is considered on the basis of existing periods of study of subjectivity problems. That allowed determining the genesis of the categories "subject" and "subjectivity".

The study of man as a subject of activity involves the definition of the theoretical postulates of the subjectivity, transformative activity of a person, the justification of the factors of this activity and the mechanisms of manifestation.

With the advent of consciousness and man as the carrier of consciousness, the division of the world into a subject and object occurs. The discovery of the object of the world, as well as the emergence of a sense of subjectivity is carried out by man. It can not be said that before and without man the world would be unchanged and nothing would have happened in it. However, with the advent of man there was the possibility of a qualitatively new transformation of the world, thanks to the human ways of transformation through the mind, spirituality, moral responsibility of man.

The problem of generalization and interpretation of various variants of understanding by subjects of subjectivity from philosophical, social, psychological and pedagogical views is singled out.

Today we can state that the subjectivity of the individual is, on the one hand, the result of educational preparation, and on the other - a holistic independent development of the individual, which is characterized by activity, initiative, responsibility, the ability to purposeful personal and educational self-improvement and changes.

Keywords: a subject; personality; subjectivity; subject manifestations; pedagogical process.

П остановка проблеми. Людська природа досить загадкова і не може бути вивчена до кінця: відтворена в серії експериментів, описана обмеженим набором термінів і понять і так далі, тобто принципово неверіфікована. Одночасно кожне дослідження так чи інакше є проекцією деякої філософії людини, а точніше погляду на неї з тієї суб’єктивної науки або практики, яку обирає дослідник.

Вивчення людини як суб'єкта діяльності передбачає визначення теоретичних постулатів суб'єктної, перетворювальної активності людини, обгрунтування факторів цієї активності та механізмів прояву.

3 виникненням свідомості і людини як носія свідомості відбувається поділ світу на суб'єкт і об'єкт. Відкриття об'єктності світу, так само як і виникнення відчуття суб'єктності здійснюється людиною. Не можна сказати, що до і без людини світ був би незмінний і нічого в ньому не відбувалося б. Однак, з появою людини виникла можливість якісно нового перетворення світу, 
завдяки людським способам перетворення за допомогою розуму, духовності, моральної відповідальності людини.

3 точки зору філософської антропології під світом розуміються чотири форми буття природа, суспільство, людина, культура. Людина присутня у всіх цих формах як ініціатор системи відносин з ними і перетворювач цих відносин [6].

Після перетворенням світу людина починає вибудовувати своє ставлення до світу, змінюючи при цьому самого себе. Зміна людиною себе особлива форма перетворювальної діяльності [7].

“Відкриття” суб'єктом цієї нової для себе якості буття означає початок змін в самому суб'єкті. Новизна перетворень, вироблених людиною в природі, пов'язана з цією специфікою: людина не просто змінює світ, вона змінюється разом $з$ ним і змінюється завдяки виробленим змін. “... Той пошук, ту практичну діяльність, той досвід, за допомогою яких суб'єкт здійснює у самому собі перетворення" В.П. Зінченко слідом за М. Фуко називає духовністю $[5,275]$.

Зазначимо, що ця проблема $є$ міждисциплінарною й перебуває на стику психології, педагогіки, соціології, унаслідок чого в науці наявна велика кількість варіантів постановки й розв' язання цієї проблеми. Оскільки аналіз буде здійснено 3 педагогічного погляду, він суттєво відрізнятиметься від філософських, психологічних і соціологічних трактувань суб’ єктності. Нашу увагу привертає проблема розуміння цього поняття 3 педагогічного погляду, тобто педагогічний аспект трактування цього процесу.

Аналіз основних досліджень і публікацій, в яких започатковано розв'язання даної проблеми. Наприкінці ХХ століття 3'явилось широке коло досліджень (у межах суб'єктного підходу), в яких активно презентовано нове бачення особистості через становлення іï суб'єктності (Н. Богданович, А. Брушлінський, В. Петровський, В. Татенко та ін.), аналіз категорії “суб'єкт”, особливої уваги заслуговують питання прояву суб' єктності особистості як результату впливу спеціально організованого освітнього середовища (А. Боднар, Ю. Журат, О. Вишневський, Я. Кодлюк).

Формування мети статті. У статті розкривається специфіка людського способу існування як активно перетворююча, свідома, громадська діяльність; дано визначення суб'єктності та суб'єкту, розглянуті основні атрибутивні характеристики цих особистісних властивостей.

До недавнього часу термін “суб'єктність” сприймався вельми курйозно, майже як помилкова версія терміну “суб'єктивність”. Диференціація цих слів була настільки нечітко визначена, що одне з них часто підміняло інше і виводилося як просте похідне поняття “суб'єкт”. Цими термінами позначалося все те, що висловлює упереджене ставлення людини до чогонебудь.

Актуальність цієї проблеми змушує нас звернутися до численних наукових трактувань $\mathrm{i}$ досліджень, які дозволили визначити генезис категорій “суб'єкт” і “суб’єктність”. Численні наукові дослідження були запропоновані в психології, філософії й соціальній педагогіці, унаслідок чого визначено такі аспекти вивчення цього поняття:

1) суб'єкт як різноманіття наявних форм життєдіяльності;

2) людина як суб'єкт різних видів діяльності;

3) суб'єкт як ініціатор, учасник та організатор взаємодії;

4) суб’ єкт як джерело соціальних взаємовідносин, комунікацій.

Багатозначність трактувань “суб’єктність” зумовило різні підходи до визначення його сутності. У психолого-педагогічній літературі зазначено, що суб'єкт - “творець своєї історії, вершитель свого життєвого шляху” $[3,15]$.

Проаналізувавши весь попередній досвід 3 вивчення проблеми співвідношення понять “суб'єкт” і “суб”єктність” у психологопедагогічній науці, Г. Сорокових запропонувала кілька етапів становлення проблематики суб'єкта й суб'єктності у вітчизняній і зарубіжній науці.

Перший етап: кінець XIX - початок XX ст. Для цього періоду характерні передумови суб' єктної проблематики в контексті побудови концепції особистості, яка поєднує філософські й психологічні підходи вивчення й дослідження цієі проблеми. Питанням розвитку особистості займався К. Юнг, який розглядав розвиток особистості як динамічний процес, еволюцію впродовж усього життя. Учений стверджував, що остаточна мета - це повна реалізація “Я”, тобто становлення єдиного, неповторного й цілісного індивіду.

Другий етап: 1930 - 1960 pp. Для цього етапу характерні поява й безпосередньо дослідження суб' єктної проблематики в контексті особистості як суб'єкта діяльності, що було запропоновано в роботі С. Рубінштейна “Основи загальної психологіі”. Учений стверджував, що “специфіка процесу людської діяльності полягає в тому, що цей процес здійснюється самою людиною” [9, 94].

Науковець обгрунтував концепцію, яка розкриває діалектику взаємодії суб'єкта й об'єкта 

У ПРОЦЕСІСАМОУСВІДОМЛЕННЯОСОБИСТОСТІ

- діалектику практичної діяльності людей. Крім того, дослідник утілив методологічну конкретизацію філософського поняття “суб'єкт” $[13,32-33]$.

У сучасній трактовці поняття “суб'єкт” - це індивід, який активно діє, пізнає й має волю та свідомість. Саме він один із перших використав поняття “суб'єкт” у психологічній антології, у реальному існуванні особистості. Учений розглядає поняття суб'єкта 3 позицій творця власного життя. Отже, С. Рубінштейну належить найрозвиненіша філософсько-психологічна концепція суб'єкта, яка розкриває особливе місце й роль людини у світі.

Науковець запропонував і розробив базові характеристики суб'єкта, зокрема активність, здатність до саморозвитку, самодетермінації, саморегуляції, самовдосконалення [9,163]. У концепції С. Рубінштейна, особливо в розробці теорії про характер та якісну своєрідність людини, зазначено, що основу становить саме суб'єктність людини.

У цей період з'являються публікації, у яких розкрито різні концепції природи психічної активності суб'єкта. Проблему “особистість суб' єкт” активно досліджують радянські науковці й дослідники.

Третій етап: 1960 - 1980 рр. На цей час закріплюються основні ідеї щодо поняття суб'єкта в концепціях адаптації, персоналізації(К. АбульхановаСлавська, Б. Ананьєв, А. Брушлинський,В. Петровський, О. Леонтьєв та ін.).

К. Абульханова-Славська вважає, що саме завдяки цій концепції суб'єкта життєдіяльності значною мірою вдалося з'ясувати специфіку самої особистості. Розглядаючи зміст категорії “суб'єкт”, науковець зауважує, що “...зовсім не кожен може стати суб'єктом свого життя” $[2,76]$. Щодо визначення поняття “суб' єкт” науковець уважає, що поняття особистості потребує іншого включення до процесу життєдіяльності, тобто створення власного поля особистісної активності в розумінні можливостей - це робить особистість суб'єктом творчості. Так, суб'єкт сам ставить перед собою проблеми, виходить поза їх межі й формує уявлення про дійсність [2, 258].

Особливу увагу у вивченні категорії суб'єкта в психології приділяв А. Брушлинський: суб'єкт завжди є особистістю, але його зміст є ширшим ніж зміст поняття “особистість”, тобто суб'єкт перебуває на вищому рівні активності, системності й автономності. Крім того, науковець додає поняття “суб'єктності” й визначає його як системну цілісність всіх складних і суперечливих якостей суб' єкта, насамперед психічних процесів, станів і якостей. Отже, А. Брушлинський розрізняє поняття “суб'єкт” і “суб'єктність” [3].

Четвертий етап: 1980 р. - до сьогодні. На цьому етапі відбувається інтенсивне дослідження проблематики суб'єктності на міждисциплінарному рівні, яка подана в низці концепцій суміжних наук: педагогічна психологія, соціальна педагогіка, теорія і методика навчання та виховання, теорія й методика професійної освіти тощо.

Iз позицій гуманістичної парадигми український педагог М. Лазарєв зазначає, що суб'єктність стає провідним принципом цієї парадигми, оскільки вимагає інтеграції в освітньому процесі сутнісних цінностей сьогоднішнього й завтрашнього дня демократичного суспільства: самостійність, автономність суб'єкта життєдіяльності, з одного боку, i його підвищена індивідуальна відповідальність перед собою й суспільством, що має підкріплюватися творчою активністю, ініціативністю, продуктивністю, - з іншого [8, 123].

У контексті визначення сутності поняття “суб'єктність” стає безсумнівною проблема узагальнення й інтерпретації різних варіантів розуміння науковцями суб'єктності 3 філософського, соціального, психологічного й педагогічного поглядів. Зрозуміло, що сам термін уперше почали досліджувати в психології. Так, виникло розуміння важливості зіставлення категорій “суб'єкт” і “особистість” та різнобічного аналізу їхнього тісного зв’язку на різних етапах розвитку людини.

У загальнофілософському контексті виділяють такі основні характеристики суб'єкта діяльності:

1) суб' єкт передбачає наявність об'єкта;

2) суб'єкт суспільний за формою, засобами, способами своєї пізнавальної або практичної діяльності;

3) суспільний суб'єкт має конкретну, індивідуальну форму реалізації, колективний суб' єкт наявний у кожному індивіді й навпаки;

4) діяльність, яка свідомо регулюється, завжди суб'єктна, у ній формується й сам суб'єкт;

5) суб'єкт індивідуальної діяльності - свідомо діюча особа;

6) суб'єктність визначається системою відносин з іншими людьми;

7) суб'єктність - це неподільна цілісність спілкування, діяльності, самосвідомості й буття;

8) суб'єктність є динамічним началом, яке не існує поза самою взаємодією - міжособистісною, соціальною, діяльнісною;

9) суб'єктність є категорією інтерпсихічною;

10) особистість як суб'єкт передбачає спрямованість, мотиви, ставлення до 


\section{РЕТРОСПЕКТИВНИЙ АНАЛІЗСТАНОВЛЕННЯ ОНТОЛОГІЧНОГО СТАТУСУ СУБ'ЄКТНОСТІ У ПРОЦЕСІСАМОУСВІДОМЛЕННЯОСОБИСТОСТІ}

навколишнього, до діяльності, себе, саморегуляцію, яка виявляється в таких якостях, як зібраність, організованість, самодисципліна, креативність, інтелектуальні риси індивідуальності $[11,837]$.

Відомий науковець і педагог В. Сластьонін зазначає, що в сучасній психологічній i педагогічній науці поняття “суб'єкт” розглядають переважно у двох значеннях: як суб'єкт

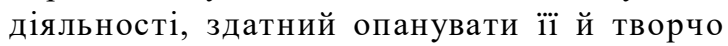
перетворити, та як суб'єкт життя, внутрішнього світу, здатний будувати стратегію й тактику своєї життєдіяльності. Внутрішня організація суб'єкта містить такі психологічні структури, які забезпечують можливості людини реалізувати себе як творця, організатора й розпорядника власним життям: спонукання, орієнтація, планування, організація й спрямованість діяльності, механізми їі регуляції й засоби здійснення [12, 264].

Із психологічного погляду науковець О. Сергієнко вважає, що цінність категорії суб'єкта для психолого-педагогічної науки полягає в кількох основних аспектах: по-перше, категорія суб'єкта дозволяє звернутися до цілісності вивчення людини, формування її особистісних і професійних якостей; по-друге, категорія суб'єкта дозволяє поєднати розрізнені аспекти вивчення індивідуальності в єдину інтегративну індивідуальність людини 3 психологічнопедагогічного погляду, i, по-третє, категорія суб'єкта надає можливість вивчення діяльності, зумовленої внутрішнім світом людини, тї суб'єктними мотивами, вибором, iіï активною побудовою моделі життєвого шляху. Науковець пропонує таке гіпотетичне вирішення: “особистість (персона) - це стрижнева структура суб'єкта, яка визначає загальне спрямування самоорганізації й саморозвитку. Особистість установлює напрямок рухомості, суб'єкт - ¥ї конкретну реалізацію через координацію вибору цілей і ресурсів індивідуальності людини" [10, 128]. Вочевидь, особистість містить зміст внутрішньої індивідуальності людини, а суб' єкт поставатиме як реалізація в певних обставинах та умовах життєвих задумів. Рівень узгодженості в розвитку особистості й суб'єкта є спонтанність поведінки людини. Отже, якщо запропонувати аналогію 3 мовою, то спонтанне використання мовленнєвих одиниць означає володіння мовою як засобом спілкування. Так і спонтанне використання індивідуальності особистості для досягнення й реалізації життєвих задумів є суб’єктністю суб'єкта.

Суб'єкт реалізується у власних життєвих відносинах як цілісне психічне новоутворювання. У багатьох психолого-педагогічних дослідженнях підкреслена саме цілісність суб'єкта. Так, для аналізу й проектування процесу формування суб' $є$ ктності студентів передбачене використання принципу цілісності для виявлення характеристик ситуацій і умов, що сприятимуть забезпеченню одночасного й узгодженого формування всіх аспектів суб'єктності.

А. Деркач і Е. Сайко визначають два аспекти в контексті визначення поняття суб'єкта, його сутнісної характеристики як явища соціального світу та функції в розвитку соціального, а також розуміння суб'єктного зростання конкретної людини. По-перше, це реальність суб'єкта, що містить його структурно-змістовну, функціональну сугність і визначає людину як суб'єкт уїі людській визначеності. Тобто суб'єкта не існує взагалі поза людиною, існує людина як суб'єкт, який є носієм і творцем соціальної форми життя, удосконалює суб'єктність як соціального феномену. По-друге, це реальність певного суб'єкта, який реалізує в життєдіяльності суб' єкта й здійснює історичний та індивідуальний розвиток, застосовуючи відповідні рівні суб'єктності як суб'єкта [4, 130 - 131].

Висновки 3 даного дослідження i перспективи подальших розвідок у даному напрямку. На сьогодні ми можемо констатувати, що суб'єктність особистості є, з одного боку, результатом освітньої підготовки, а 3 іншого цілісним самостійним розвитком особистості, для якого характерна активність, ініціативність, відповідальність, здатність до цілеспрямованих особистісних і навчальних самовдосконалень і змін.

Здійснений огляд сутності поняття суб'єктності дає нам підстави перейти до визначення детермінантів і структури, які становлять основу процесу формування суб'єктності учнів старшої школи в контексті компетентнісного підходу.

\section{ЛІТЕРАТУРА}

1. Абульханова-Славская К.А. Деятельность ипсихология личности: монография /К.А. АбульхановаСлавская. - М. : Наука, 1980. - 334 с.

2. Абульханова-Славская К.А. Стратегия жизни: монография / К.А. Абульханова-Славская. - М. : Мысль, 1991. - 299 с.

3. Брушлинский А.В. Деятельность субъекта как единство теории и практики / А.В. Брушлинский // Психологический журн. - 2000. - Т. 21. - № 6. - С. $5-11$.

4. Деркач А.А. Субъектность субъекта в акмеологическом развитии и проблемы его 


\section{РЕТРОСПЕКТИВНИЙ АНАЛІЗСТАНОВЛЕННЯ ОНТОЛОГІЧНОГО СТАТУСУ СУБ'ЄКТНОСТІ У ПРОЦЕСІСАМОУСВІДОМЛЕННЯ ОСОБИСТОСТІ}

субъектного самоосуществления / Анатолий Деркач, Эди Сайко // Мир психологии. - 2008. № 3. - С. $205-219$.

5. Зинченко В.П., Моргунов Е.Б. Человек развивающийся. Очерки российской психологии. М.: Тривола, 1994. 304 с.

6. Каган М.С. О соотношении понятий “природа”, “общество”, “человек”, “культура” в системе философских категорий // Мировоззренческое содержание категорий и законов материалистической диалектики. / отв. редактор В. И. Шинкарук, А.И. Яценко Киев: Наукова думка, 1981. С.139 - 155.

7. Каган М.С. Человеческая деятельность. М.: Политиздат, 1974. - 328 с.

8. Лазарєв М.О. Евристично-модульне навчання як інтеграційна особистісно зорієнтована технологія формування творчої особистості / М.О. Лазарєв // Наук. часопис НПУ імені М.П. Драгоманова. - 2007. - Сер. 16. - Вип. 7. - С. 123 - 129.

9. Рубинштейн С.Л. Основы общей психологии / С.Л. Рубинштейн. - СПб: Питер, 2000 - 712 с.

10. Сергиенко Е.А. Системно-субъектный подход: обоснование и перспектива / Е.А. Сергиенко // Психологический журн. - 2011. - Т. 32. - № 1. С. $120-131$.

11. Скорич Л.П. Суб'єктність в освітньому процесі / Л.П. Скорич // Вісн. Кам’янець-Поділ. нац. ун-ту імені Івана Огієнка. - 2011. - Вип. 11. - C. $836-850$.

12.СластенинВ.А.Избранныетруды/В.А. Сластенин. - М.: Издательский Дом МАГИСТР-ПРЕСС, 2000. -488 c.

13. Сороковых Г.В. Субъектно-деятельностный подход в лингвистической подготовке студентов неязыковых вузов: дис. ... д-ра пед. наук: 13.00.08., 13.00.02. / Сороковых Галина Викторовна. - Курск, 2004. - 460 с.

\section{REFERENCES}

1. Abulhanova-Slavskaya, K.A. (1980). Deyatelnost i psihologiya lichnosti: monografiya [Activity and psychology of personality: monograph]. Moscow: Nauka Publ., 334 p. [in Russian].

2. Abulhanova-Slavskaya, K.A. (1991). Strategiya zhizni: monografiya [Strategy of life: monograph]. Moscow: Thought Publ., 299 p. [in Russian].

3. Brushlinskij, A.V. (2000). Deyatelnost subekta kak edinstvo teorii i praktiki [Activity of the agent as a unity of theory and practice]. Psihologicheskij zhurn. Issue, 21.pp. 5 - 11. [in Russian].
4. Derkach, A.A. \& Sajko, Edi (2008). Subektnost subekta $v$ akmeologicheskom razvitii i problemy ego subektnogo samoosushestvleniya [The agent's agency in acmeological development and the problems of its agent self-fulfillment]. The world of psychology. №3, pp. 205 - 219. [in Russian].

5. Zinchenko, V.P. \& Morgunov, E.B. (2008). Chelovek razvivayushijsya. Ocherki rossijskoj psihologii [Man developing. Essays on Russian Psychology]. Moscow: Trivola Publ., 304 p. [in Russian].

6. Kagan, M.S. (1981). O sootnoshenii ponyatij "priroda", "obshestvo", "chelovek", "kultura" v sisteme filosofskih kategorij [On the relationship between the concepts of "nature", "society", "man", "culture" in the system of philosophical categories]. Worldview of the categories and laws of materialistic dialectics. Kyiv, pp. 139-150. [in Russian].

7. Kagan, M.S. (1974). Chelovecheskaya deyatelnost [Human activity]. Moscow: Politizdat Publ., 328 p. [in Russian].

8. Lazaryev, M.O. (2007). Evristichno-modulne navchannya yak integracijna osobistisno zoriyentovana tehnologiya formuvannya tvorchoyi osobistosti [Heuristic-modular training as an integration personally oriented technology of forming a creative personality]. Scientific. magazine NPU named after MP Drahomanov Series: 16,vol. 7, pp. 123 - 129. [in Ukrainian].

9. Rubinshtejn, S.L. (2000). Osnovy obshej psihologii [Fundamentals of General Psychology]. Saint Petersburg: Piter Publ., 712 p. [in Russian].

10. Sergienko, E.A. (2011). Sistemno-subektnyj podhod: obosnovanie i perspektiva [System-agent approach: justification and perspective]. Psychological Journal. Issue 32, no. 1, pp. 120 131. [in Russian].

11. Skorych, L P. (2011). Subiektnist v osvitnomu protsesi [Agency in the educational process]. Bulletin of the Kamyanets-Podilsky National University named after Ivan Ogienko. Vol. 11, pp. 836 - 850. [in Ukrainian].

12. Slastenin, V.A. (2000). Izbrannye trudy [Selected Works]. Moscow: Publishing House MASTER-PRESS, 488 p. [in Russian].

13. Sorokovyh, G.V.(2004). Subektno-deyatelnostnyj podhod v lingvisticheskoj podgotovke studentov neyazykovyh vuzov [Agent-activity approach in the linguistic training of students of non-linguistic universities]. Doctor's thesis. Kursk, 460 p.

Стаття надійшла до редакції 20.08.2018

\section{G58080ल2058080}

